\title{
Cross-Sectoral Engagement in the Eradication of Schistosomiasis in Indonesia
}

\author{
Gunawan $^{1}$, Junus Widjaja ${ }^{1}$, Phetisya Pamela Frederika Sumolang ${ }^{1} \&$ Hayani Anastasia ${ }^{1}$ \\ ${ }^{1}$ Researcher of Donggala Health Research and Development Center, Donggala, Indonesia \\ Correspondence: Gunawan, Donggala Health Research and Development Center, Donggala District, Indonesia. \\ Tel: 62-8229268-4506.
}

Received: April 7, 2021 Accepted: August 27, 2021 Online Published: September 13, 2021

doi:10.5539/gjhs.v13n10p82

URL: https://doi.org/10.5539/gjhs.v13n10p82

\begin{abstract}
Background: Indonesia has planned a roadmap to eradicate schistosomiasis and achieved the elimination of schistosomiasis by 2025. Through cooperation between the Ministry of Health and the Ministry of National Development Planning or the National Development Planning Agency (Bappenas). The roadmap is a reference to plan the shared action multiple sectors, central-regional and communal coordinated by the National Development Planning Agency (Bappenas) and Development Planning Agency at Sub-national Level (Bappeda).

Objective: analyzing cross-sectoral involvement in 2019 in efforts to eradicate schistosomiasis. The research method is to analyze data and information regarding the schistosomiasis control program in 2019.

Material and Methods: The data and information in the study came from six Regional Apparatus Organizations (OPD) in Poso and seven OPDs in Sigi Central Sulawesi.

Result: This study reveals that, based on the roadmap to eradicate schistosomiasis, mass treatment regarding schistosomiasis for humans is $70-94 \%$; mass medication for livestock is $50 \%$; surveillance on intermediate snails, humans, and animals is 70-94\%; 6,000 animals and 49\%; the campaigns for behavioral changes and an increase in community participation in 18 villages and multi-sector coordination and intensive integrated supervision is $50 \%$. Meanwhile, public toilets in the focus areas and livestock management have not proceeded. The prevalence of schistosomiasis in humans showed yields of $0.13 \%, 0 \%$, and $0.0 \%$ in the Napu, Bada, and Lindu Plateaus. In addition, the prevalence of schistosomiasis in animals was $3.4 \%$ and $2.3 \%$ in buffalo and horses.
\end{abstract}

Conclusion: Schistosomiasis control in terms of health can reduce the prevalence of schistosomiasis in humans. And schistosomiasis control is not a priority program in terms of agriculture. Who did not build schistosomiasis control programs in 2019 upon good coordination between the central and local governments?

Keywords: eradication roadmap, schistosomiasis, and cross-sectoral

\section{Introduction}

Schistosomiasis is one of the parasitic diseases of neglected tissue (Mitra \& Mawson, 2017). Schistosomiasis is reportedly endemic in 78 countries. There were 280 million people infected by schistosomiasis in 2018. Schistosomiasis in humans and animals was caused by Schistosoma worms. There are six Schistosoma species, i.e., S. guineensis, S. haematobium, S. intercalatum, S. japonicum, S. mansoni, and S. Mekongi (Knowles et al., 2015; Jourdan, Montresor, \& Walson, 2017; Kabore et al., 2017; Ross et al., 2017; Yu et al., 2017).

Schistosomiasis in Indonesia is caused by Schistosomia japonicum and the intermediate snail Oncomelania hupensis lindoensis. This disease can only be found in three areas that are Lindu, Napu, and Bada Highlands Central Sulawesi (Satrija, Ridwan, \& Rauf, 2015; Widjaja et al., 2017). The efforts made to control schistosomiasis in 2005 could reduce the prevalence from $37 \%$ to $1 \%$ in Napu and Lindu Highlands. Nevertheless, in 2008-2011, the prevalence of schistosomiasis varied in a range of $0.3-4.8 \%$ and $0.8-3.2 \%$ in Napu and Lindu Highlands, respectively (Sugiarto \& Soeyoko, 2010; Satrija, Ridwan, \& Rauf, 2015). The elimination of this disease demands an integrated schistosomiasis control (Sugiarto \& Soeyoko, 2010; Gunawan et al., 2014; Nurwidayati et al., 2016; Widjaja et al., 2017).

To support the eradication of schistosomiasis, the roadmap to eradicate schistosomiasis $2018-2025$ is issued. The roadmap aims to elevate the commitment of stakeholders, at either the central or local level, to support the 
eradication of schistosomiasis in Indonesia. In general, the roadmap to eradicate schistosomiasis 2018-2025 mentions the strategy for eradication, stages of eradication, selection of target focus and target achievement, program, and cross-sectoral activity mapping, and evaluation monitoring mechanism to evaluate the outcome. Furthermore, the roadmap is expected to guide the program orientation, activities, and budget from all relevant stakeholders at the central and local levels, generating a synergy to eradicate schistosomiasis. The roadmap is funded by multiple financing sources, i.e., APBN, APBD, regional transfer funds (DAK), or village funds (Kementerian Kesehatan, 2019).

According the roadmap to eradicate schistosomiasis, divided into three phases, the stages to achieve the elimination of schistosomiasis are:

\section{a. Acceleration Phase (2018-2019)}

At this phase, we intervene in intermediate snails, humans, and animals through a multisectoral collaboration using the one health approach. This phase aims to reduce the prevalence of baseline prevalence (2017) to $0 \%$ at the end of 2019 (Bappenas, 2019).

b. Maintenance and Post-surveillance Phases (2020-2024)

The prevalence of $S$. japonicum infection in intermediate snails, humans, and animals successfully reduced to $0 \%$ at the acceleration phase will be contained for five years. This phase is crucial to meet the WHO's requirements to verify the eradication of schistosomiasis in Indonesia in 2025. At this phase, for the surveillance activity, we use diagnostic techniques with high sensitivity, such as serologic tests and LAMP. The action is essential to assure no schistosomiasis cases in humans, animals, and snails. The surveillance in humans is conducted to the entire population/total screening in 2020. In 2021-2024, the surveillance of humans was performed in hotspot villages.

c. Eradication Declaration Phase (2025-so on)

The declaration of the eradication of schistosomiasis is performed after WHO's verification to the post-surveillance intervention outcome confirming no schistosomiasis infection in humans, animals, and snails in the endemic area for five consecutive years. (Bappenas, 2019)

One of the challenges in this program is a lack of supports from both stakeholders and the budget allocated for this program. Besides, despite the existence of an integrated team of schistosomiasis control steered by the Governor of Central Sulawesi, the budgeting and provision are not following the epidemiological evidence. That situation is worsened by a lack of coordination made by the Ministry of Health, the Ministry of Agriculture, and the Ministry of Environment when implementing the strategy for controlling schistosomiasis (National Institute of Health Research and Development Ministry of Health Republic of Indonesia, 2019).

\section{Method}

In this research, data and information were collected from six Regional Apparatus Organizations (OPD) in Poso and seven OPDs in Sigi Central Sulawesi. The data and information collected include the schistosomiasis control implementation program in 2019. The data collection methods are

a. Interviewing the schistosomiasis program holder or the representatives of OPDs.

b. The data are collected from literature, journals, newspapers, statutory provisions, and other supporting documents.

c. Data collection: the parameters studied are schistosomiasis control activities that have been made by the Roadmap to Eradicate Schistosomiasis 2019.

\section{Results}

\subsection{Cross-Sectoral Engagement to Control Schistosomiasis in Poso}

\subsubsection{Department of Agriculture}

\section{- Facilities and Infrastructures Division}

The Facilities and Infrastructures Division is responsible for two physical tasks, i.e., the construction of the DAM trench and irrigation. The construction funds are from general allocation funds (DAU) and regional transfer funds (DAK). DAM trenches are built in Wanga, Wuasa, Alitupu, Watutau, Kalimago, Maholo, Tomehipi, and Tuare. Moreover, irrigations are self-provided by farmer associations in Wanga, Betue, Lengkeka, and Bariri.

\section{- Animal Farming Division}

The animal farming division is responsible for mammal fecal sampling, animal care, livestock grazing fences, and 
duck distribution.

- Mammal fecal sampling is performed twice. The first sampling is performed on 1,000 mammals in Lore Barat, and the second one is completed to 800, 200, 200, and 200 mammals in Lore Barat, Lore Timur, and Lore Tengah, Lore Peore, and Lore Utara, respectively. The funds allocated for the program are from the Local Government Budget (APBD).

- Mass drug administration in an animal is performed by administering praziquantel to several species of mammals, i.e., cows, pigs, buffalos, and dogs. The funds allocated for this program are from the Local Government Budget (APBD).

- Construction of livestock grazing barbed wire fences is conducted in Winowanga Lore Timur. The funds, IDR112,000,000.00, are from APBD II and given to the Nunurembe farmer association.

- Ducks are distributed to some communities in Lore Timur and Lore Tengah. In Lore Timur, ducks are distributed to the Maewa communities in Winowanga (female ducks of 150 and male ducks of 29) and Kalemago (female ducks of 155 and male ducks of 29). Moreover, in Lore Tengah, ducks are distributed to the Ariama Jaya community (female ducks of 155 and male ducks of 29) and the Alam Lestari community (female ducks of 155 and male ducks of 29) in Rompo.

\subsubsection{Public Works and Public Housing Office}

Regarding schistosomiasis control, the Public Works and Public Housing Office is responsible for six activities, i.e., providing drinking water facilities and infrastructures for the low-income community, providing wastewater facilities and infrastructures, managing the Integrated Participatory Development and Management of Irrigation Program (IPDMIP), constructing infrastructures, i.e., roads and bridges, and rehabilitating/maintaining roads.

\section{- Drinking-water Facilities and Infrastructures Provision for the Low-income Community}

Through the Ministry of Public Works and Public Housing (PUPR), the government constantly fulfills the public needs for drinking water and target the escalation of safe access to drinking water at the end of 2019 by 27.6 million house connections (SR) through a piping network, especially for the low-income community (MBR). The Public Works and Public Housing Office responds to this program by providing drinking water facilities and infrastructures in Maholo.

\section{- Wastewater Facility and Infrastructure Provision}

This activity is in the form of communal-scale septic tank construction in Wuasa.

\section{- Integrated Participatory Development and Management of Irrigation Program (IPDMIP)}

IPDMIP is the government's program specifically in irrigation that aims to sustain an irrigation system authorized by the central, provincial, or district government. This program is implemented in Tamadue, Mekarsari, and Wuasa.

\section{- Construction of Other Infrastructures, i.e., Roads and Bridges and Road Rehabilitation/Maintenance}

The construction of several infrastructures, i.e., roads and bridges and road rehabilitation/maintenance, are conducted in some villages.

\subsubsection{Department of Marine and Fisheries}

In terms of schistosomiasis control, the Department of Marine and Fisheries is responsible for processing, maintaining, and activating ponds and restocking Nile tilapia seeds.

\section{- Processing, Maintaining and Activating Ponds}

This program is a Nile tilapia pilot package in ponds in Lore Barat, Lore Selatan, Lore Tengah, and Lore Peore. The program fund is from DAK. The assistances given are in the forms of pond construction, fish food, and fish seeds.

\section{- Restocking Nile Tilapia Seeds}

This program is conducted in Lake Tonawuwu Torire Lore Tengah. In this program, the fish farming groups in Dodolo are granted 9,000 common carp seeds, and the fish farming group in Wanga is given Nile tilapia farming training.

\subsubsection{Health Office}

Engaging with schistosomiasis control, the Health Office executes other programs. It is responsible for controlling snails by spraying, especially in the endemic villages, and procuring community-based total sanitation (STBM) in 
sub-districts in Napu Highlands. Furthermore, it also arranges mini-workshops for health and integrated service post cadres, campaigning to eliminate schistosomiasis. There are also some other activities performed by the Health Office, i.e., socialization and GEMA BERAKSI Focus Group Discussion (FGD) followed up by GEMA BERAKSI supervision, workshops for counselors, and mass health care.

\subsubsection{Office of Rural Community Employment}

Regarding schistosomiasis control, the Office of Rural Community Employment is responsible for training the assistant staff in schistosomiasis-focus villages. The training participants are from the endemic sub-districts. As mentioned in the Roadmap 2019, the Office of Rural Community Employment is scheduled to perform several activities, i.e.:

1) Intensive farm management

2) Land clearing (hoarding)

3) Provision of access to permanent health toilets

4) Toilet maintenance and provision in the focus areas. The performance of this activity is assisted by the Public Works and Public Housing Office.

5) Cadre activities campaigning the elimination of schistosomiasis

As we currently observe, the villages are scheduling some agendas that can be synergized with the schistosomiasis programs. The plans include clean water provision, healthy toilet provision, water channel construction in farming areas, and community empowerment by cadres. These activities fund the village government budget (APB Desa).

The Office of Rural Community employment encourages the village fund to provide permanent healthy toilets and clear land by hoarding swamps.

\subsubsection{Ministry of Education and Culture}

In terms of schistosomiasis control, the Ministry of Education and Culture plays an essential role in schistosomiasis socialization to teachers and students in Lore Selatan and Lore Barat. The Health Office in Poso engages in this program as the speaker.

3.1.7 Planning, Development, Research, and Development Agency at Sub-national Level (Bapelitbangda)

Regarding schistosomiasis control, the Planning, Development, Research and Development Agency at Sub-national Level (Bapelitbangda) mainly contributes to supervising and evaluating the program implemented by OPD schistosomiasis control in Poso by referring to the roadmap to eradicate schistosomiasis.

\subsection{Cross-sectoral Engagement to Control Schistosomiasis in Sigi}

\subsubsection{Department of Agriculture, Food, and Fisheries}

In schistosomiasis control, the Department of Agriculture, Food, and Fisheries designs three programs, i.e., the developing fish freshwater cultivation areas, developing fish cultivation areas using the mina PADI system and restocking fish.

- Developing Fish Freshwater Cultivation Areas in Lindu

This program is implemented in Puroo Lindu and funded by DAK.

- Developing Dish Cultivation Areas with the Mina Padi System

This program is implemented in Puroo, Langko, and Olu and is fund by the State Budget.

\section{- Restocking Fish}

This program is implemented in Puroo, Langkom Tomado, and Olu and is fund by DAU.

\subsubsection{Department of Animal Husbandry and Animal Health}

The Department of Animal Husbandry and Animal Health, partaking in schistosomiasis control, implements some programs (in coordination with the Ministry of Agriculture), i.e., mass health care for animals, animal fecal examination, animal health service strengthening through the development of Puskeswan, and livestock grazing management.

\subsubsection{Office of Rural Community Employment}

The Office of Rural Community Employment, in schistosomiasis control, motivates the community to use village funds (ADD) 2019 to cultivate idle land into a public plantation, construct village roads, develop drainage in focus 
areas, make the road of production bags, and give schistosomiasis cadres proper incentive.

\subsubsection{Health Office}

Participating in schistosomiasis control, the Health Office implements the following programs: laboratory building rehabilitation, shopping for fecal examination materials, shopping for mouse traps, prevalence supervision, mass health care, and snail survey.

\subsubsection{Public Works and Public Housing Office}

In schistosomiasis control, the Public Works and Public Housing Office implements several programs, i.e., developing a catchment area, developing communal toilets, strengthening irrigated areas in Puroo, and rehabilitating roads.

\subsubsection{Development Planning Agency at Sub-national Level (Bappeda)}

Regarding schistosomiasis control, the Development Planning Agency at the sub-National Level (Bappeda) holds a cross-sectoral coordination meeting at a district level.

\subsubsection{Food Crops and Horticulture Service}

In schistosomiasis control, the Food Crops and Horticulture Service implements several programs; such as the construction of farm lines, development of DAM ditches, construction of official BPP of Lindu houses, construction of tertiary irrigation networks, procurement of hand tractors and 2-wheel tractors, procurement of coffee seeds, planting of cocoa seeds, planting of rambutan seeds, planting of durian seeds, and optimizing paddy fields.

\subsection{Achievements in Schistosomiasis Control Based on the Key}

Cross-sectoral involvement in schistosomiasis control 2019 in the Roadmap for The Eradication of Schistosomiasis in Poso and Sigi central Sulawesi has been well implemented. The program achievements are listed in Table 1.

Table 1. The Achievements of Schistosomiasis Control Program 2019 Based on the Key Intervention in Roadmap to Eradicate Schistosomiasis 2019

\begin{tabular}{|c|c|c|c|c|}
\hline No. & Key Intervention & Indicators of Achievement & Target 2019 & $\begin{array}{l}\text { Outcome } \\
2019\end{array}$ \\
\hline 1. & $\begin{array}{l}\text { Annual mass drug } \\
\text { administration in humans }\end{array}$ & $\begin{array}{l}\text { The proportion of the population that took } \\
\text { Praziquantel (PZQ) in } 2019\end{array}$ & $100 \%$ & $70-94 \%$ \\
\hline 2. & $\begin{array}{l}\text { Mass drug administration in } \\
\text { animals twice a year }\end{array}$ & $\begin{array}{l}\text { Proportion of livestock (cows, buffalos, } \\
\text { and horses) population administered with } \\
\text { PZQ every semester }\end{array}$ & Twice & $\begin{array}{l}\text { Once } \\
(50 \%)\end{array}$ \\
\hline 3. & $\begin{array}{l}\text { Modification of the } \\
\text { cross-sectoral integrated } \\
\text { environment }\end{array}$ & $\begin{array}{l}\text { The number of villages receiving an } \\
\text { environmental modification }\end{array}$ & 23 villages & $\begin{array}{l}\text { Seven } \\
\text { villages }\end{array}$ \\
\hline 4. & $\begin{array}{l}\text { Chemical eradication of } \\
\text { snails }\end{array}$ & $\begin{array}{l}\text { Focus area that implements chemical } \\
\text { eradication }\end{array}$ & $330,383 \mathrm{~m}^{2}$ & $\begin{array}{l}147 \text { focus } \\
\text { areas }\end{array}$ \\
\hline 5. & $\begin{array}{l}\text { Provision of drinking water } \\
\text { and sanitation }\end{array}$ & $\begin{array}{l}\text { KK coverage regarding access to drinking } \\
\text { water and sustainable proper sanitation }\end{array}$ & $\begin{array}{l}100 \% \text { access to house } \\
\text { connection, } 85 \% \text { access to } \\
\text { adequate sanitation }\end{array}$ & $\begin{array}{l}\text { Three } \\
\text { villages }\end{array}$ \\
\hline 6. & $\begin{array}{l}\text { Provision of public toilets in } \\
\text { focus areas }\end{array}$ & $\begin{array}{l}\text { The quantity of healthy and } \\
\text { well-maintained toilets in focus areas }\end{array}$ & 172 toilet units & - \\
\hline 7. & $\begin{array}{l}\text { Livestock management } \\
\text { (including animal farmer } \\
\text { group strengthening) }\end{array}$ & $\begin{array}{l}\text { The proportion of the extensive livestock } \\
\text { (cows, buffalos, and horses) population } \\
\text { prevented to got to the focus area }\end{array}$ & $50 \%$ & - \\
\hline
\end{tabular}


The proportion of the quantity of examination sample to population (humans and animals) and focus areas

100\% (humans), Humans (70-94.5\%), $100 \%$ (animals), and animals (6.000), $51 \%$ (snails) $\quad$ snails $(49 \%)$
8. Surveillance of intermediate snails, humans, and animals
Number of villages that actively give campaigns for one-health based KIE
28 villages

18 villages

9. changes and community participation strengthening

\begin{tabular}{|c|c|c|c|c|c|}
\hline 10. & $\begin{array}{l}\text { Multisectoral coordination } \\
\text { and intensive integrated } \\
\text { monitoring and evaluation }\end{array}$ & $\begin{array}{l}\text { Program coverage and } \\
\text { achievement }\end{array}$ & target & $80 \%$ & $52 \%$ \\
\hline
\end{tabular}

\section{Discussion}

Schistosomiasis control in Indonesia was initiated in 1975. In the attempts to eliminate schistosomiasis in Indonesia, in 2018, the Ministry of Health, in coordination with the National Planning Agency (Bappenas), made the roadmap to eradicate schistosomiasis. This roadmap is a reference for the shared action planning cross-sectoral, central-regional, and community. The shared action planning is coordinated by the National Planning Agency (Bappenas) and the Development Planning Agency at the Sub-national Level (Bappeda). Some sectors engaging in schistosomiasis control are the local apparatus organizations in Poso; such as the Planning, Development, Research, and Development Agency at the Sub-national Level (Bapelitbangda), Health Office, Department of Agriculture and Husbandry, Village Community Empowerment Service (PMD), Public Works and Public Housing Office (PUPR), and Fisheries Service. Meanwhile, the sectors engaging in schistosomiasis control in Sigi are the Development Planning Agency at Sub-national Level (Bappeda) Health Office, Fisheries Service, Department of Agriculture, Department of Animal Husbandry and Animal Health, Village Community Empowerment Service (PMD), Public Works and Public Housing Office (PUPR), and Food Security Service (Anastasia \& Widjaja, 2019; Anastasia et al., 2019).

After the Roadmap issuance in 2018, all sectors started designing control activities following the action plan and the roadmap to eradicate schistosomiasis. Some ministries, including the Ministry of Health, are granted a considerable amount of budget. However, the other churches, such as the Ministry of Agriculture, are granted small funding. The reason behind the different budgets is that schistosomiasis is not the program prioritized by the later ministries. The cross-sectoral budget, in terms of schistosomiasis control, comes from the State Budget (APBN), such as the regional transfer funds (DAK) and the Local Government Budget (APBD) such as the Public Allocation Fund (DAU). DAK is used in direct schistosomiasis control at the regional level and managed by the interested region or related sectors. One of the control programs implemented is schistosomiasis mass treatment managed by the Health Office in Central Sulawesi or trench DAM construction managed by the Department of Agriculture in Poso.

The schistosomiasis control outcome in 2018 has been evaluated, and the schistosomiasis control achievement at the acceleration phase is $42 \%$. That low percentage is inevitable as the date on which Roadmap to Eradicate schistosomiasis was issued is close to how schistosomiasis control programs were designed. Consequently, the programs designed are disproportional to the roadmap, and in some programs, there found no coordination between the central and local governments. That lack of coordination causes imprecise development locations (Anastasia \& Widjaja, 2019).

The schistosomiasis control outcome in 2019 has also been evaluated, and the schistosomiasis control achievement at the acceleration phase in 2019 is 52\%. In 2019, some Roadmap programs were implemented at the acceleration phase, such as mass animal medication and surveillance of humans, animals, and snails. Nevertheless, some other programs do not come with the target Roadmap achievement.

In general, schistosomiasis control programs implemented by the Ministry of Health, Provincial Health Officer, and District Health Office have been well implemented as targeted in the roadmap to eradicate schistosomiasis. The well-implemented programs are mass treatment, fecal survey, snail survey, and schistosomiasis socialization programs. The general mass treatment achievement is $>75 \%$, whereas the population coverage for the fecal survey is $>95 \%$. Some villages have a population coverage of $<95 \%$. That low coverage is induced by the situations where several people have to go to schools located outside the endemic area, that is, Napu Highlands, or work in Palu, Poso, Morowali, and other cities. Besides, pregnant or breastfeeding women are not allowed to participate in the mass treatment. The Health Office in Central Sulawesi concludes that the prevalence of schistosomiasis in humans 
in 2019 in Napu, Bada, Lindu Highlands is $0.13 \%, 0 \%$, and $0.05 \%$, respectively.

The attempts made to degenerate intermediate snails in the focus area are to spray molluscicides. This spraying is only conducted in narrow and accessible focus areas. That incomplete spraying generates focus areas that are impossible to cultivate. The snail focus areas are becoming the central issue due to many snail focus areas in farms or swamps that cannot be produced. Cross-sectoral coordination is thus required to overcome the problems in those areas. Regarding this overcoming attempt, relevant cross-sectoral coordination can be established with the Ministry of Agriculture and the Department of Agriculture or the Department of Fisheries. Furthermore, the eradication of snail focus areas should engage with the community. Some forms of the engagement are Gerakan Masyarakat Berantas Keong Schistosomiasis (Gema Beraksi) and Model Bada.

Moreover, the Ministry of Agriculture, through the Provincial and District Department of Agriculture, also participates in schistosomiasis control. Nevertheless, its programs implemented in 2019 were off-targets. The ineffective programs are trench DAM development, irrigation making, and tertiary network development. The program priority is not in the locus of the eradication of snails in the snail focus areas.

One of the essential cross-sectoral engagements is the Department of Agriculture's engagement in animal farming at the provincial or district level. The arrangement is necessary, considering that pets are also regarded as one of the schistosomiasis reservoir animals. The pets intended include cows, horses, buffalos, dogs, and pigs. The selective mass treatment of animals in the endemic schistosomiasis area has been started since 2018. In 2019, mass treatment of animals had been implemented in almost all villages. Nevertheless, some issues emerge, such as animals that die after being given the incorrect type of drugs or other drugs in an imprecise dose.

Another program implemented is making livestock sheds, especially for cows. However, the livestock shed program can only be implemented in several specific locations, and thus schistosomiasis transmission is still possible. Gunawan et al. convey that livestock, especially cows, predominantly contributes to schistosomiasis transmission in Lindu Highlands (Gunawan et al., 2014).

Meanwhile, the animal fecal examination program is conducted in 2018 and 2019. However, we found differences in the outcome of the examination performed by the UPT Veteriner Department of Animal Husbandry and Animal Health, Central Sulawesi, and that by Parasitology Laboratory, Maros Center for Veterinary Research (Balitvet). The resolution is to discuss the method to collect and examine the animal fecal sample. Furthermore, the Department of Animal Husbandry and Animal Health in Sigi 2019 indicates that the prevalence of schistosomiasis in animals in Lindu Highlands is as follows: $3.4 \%$ in cows and 2.3\% in horses.

Schistosomiasis control by the Public Works and Public Housing Office, through the Public Works Division, is conducted by the Provincial and District Public Works and Public Housing Office. The program is focused on sustaining schistosomiasis control in the endemic area, building roads and bridges, rehabilitating/maintaining roads, and procuring facilities and infrastructures regarding drinking waters through connection access using a piping network.

Meanwhile, schistosomiasis control in fisheries and marine is also performed by the Provincial and District Department of Marine and Fisheries. In 2016, the Department implemented several programs, such as fish ponds, fish food provision, fish seeding, and fish cultivation training for fish farmer groups. However, in 2018, fish ponds were built in a specific location that was not a snail focus area (Anastasia et al., 2019). Control of schistosomiasis conducted by the Fisheries Service in 2019 is to turn the snail focus area into a fish pond and distribute fish food and fish seeds. It should be constantly implemented by the community to elevate the economy of the community.

Participating in schistosomiasis control, the Provincial and District Community and Village Empowerment Service focus on schistosomiasis socialization and training. The two services make coordination regarding schistosomiasis control. The program includes encouraging the use of village funds to control schistosomiasis in the endemic village. Some villages can use the village fund by building water channels and paths leading to the garden as the snail focus area. The challenge is no village regulation that regulates the use of village funds in schistosomiasis control. Village apparatuses are inconvenient with the potential negative perception that makes them contact with legal instruments.

Bappeda also conducts coordination meetings and evaluations of cross-sectoral programs regarding schistosomiasis control. Bappeda is expected to coordinate all schistosomiasis control programs, either at the provincial or district level, by the roadmap to eradicate schistosomiasis. Also, Bappeda is expected to resolve technical or financing problems in schistosomiasis control performed by responsible sectors. 
Schistosoma japonicum shedding is in China, Indonesia, and the Philippines (Olveda and Gray, 2019). In China, Schistosomiasis control has been started since 1950. In that year, there were 11 million people allegedly infected, and the local infection level was in a range of $10-90 \%$ (Gordon et al., 2019). Observed to this day, China has managed the elimination of schistosomiasis in 6 of its 12 provinces. Considering that success, many other countries, such as Indonesia and the Philippines e, implement an analogous strategy for eliminating schistosomiasis. China, implementing the elimination of schistosomiasis, integrates programs regarding health, community, society, and economy (Chen et al., 2018). Ros et al. (2019) argue that the elimination of schistosomiasis requires supports at both provincial and district levels. However, we can see that the district level is dominant in giving supports. Besides, a team comprising doctors and nurses should be posed in every endemic village or region (Ross, Chau, Inobaya, Olveda, \& Harn, 2017).

Based on the roadmap to eradicate schistosomiasis, there are some phases to eliminate schistosomiasis. One of the phases is acceleration. At that phase, the intervention rendered to intermediate snails, animals, and humans through a multisectoral collaboration with the one-health approach can reduce the prevalence from the baseline prevalence (2017) to $0 \%$ at the end of 2019 (Bappenas, 2019). Sadly, the evidence clarifies that the majority of schistosomiasis in humans and animals is not $0 \%$. According to a schistosomiasis surveillance report by the Health Office in Central Sulawesi, in 2019, the prevalence of schistosomiasis in humans in Napu, Bada, and Lindu Highlands was $0.13 \%, 0 \%$, and $0.05 \%$, respectively. Meanwhile, the data of the Department of Animal Husbandry and Animal Health 2019 indicate that the prevalence of schistosomiasis in buffaloes and horses was $3.4 \%$ and $2.3 \%$. It implies that the eradication of schistosomiasis at the acceleration phase was not successful in 2019.

\section{Conclusion}

Schistosomiasis control in terms of health can reduce the prevalence of schistosomiasis in humans. The prevalence of schistosomiasis in humans in 2019 in Napu, Bada, and Lindu Highlands was 0.13\%, 0\%, and 0.05\%, respectively. However, schistosomiasis control in agriculture, public works, and fisheries cannot reduce the number of focus snails. Moreover, schistosomiasis control in terms of farming can reduce the prevalence of schistosomiasis in buffalos and horses by $3.4 \%$ and $2.3 \%$, respectively, yet cannot reduce the prevalence schistosomiasis in animals to $0 \%$.

Schistosomiasis control is not a priority program in terms of agriculture. Schistosomiasis control programs in 2019 were not built upon good coordination between the central and local governments.

\section{Acknowledgements}

The authors would like to express gratitude to the Health Research and Development Agency director in Donggala and all multi-sector institutions that have implemented schistosomiasis control programs.

\section{Shift Contributors}

All the authors were the main contributors: G contributes to the concept of the article's content, JW and PFS contributed to the analysis and the writing of results, and HA contributed to the discussion part and layout article.

\section{Competing Interests Statement}

The authors declare that there are no competing or potential conflicts of interest.

\section{References}

Anastasia, H. et al. (2019). Evaluation of Multisectoral Schistosomiasis Control In 2018 (pp. 217-226).

Anastasia, H., \& Widjaja, J. (2019). Engaging multisectoral collaboration to combat schistosomiasis in Napu highlands, Poso District. Central Sulawesi Engaging multisectoral collaboration to combat schistosomiasis in Napu highlands, Poso District, Central Sulawesi. https://doi.org/10.1088/1742-6596/1155/1/012111

Bappenas. (2019). Roadmap Eradication of Schistosomiasis in 2018-2025.

Chen, J., Xu, J., Bergquist, R., Li, S. Z., \& Zhou, X. N. (2018). "Farewell to the God of Plague": the importance of political commitment towards the elimination of schistosomiasis. Tropical Medicine and Infectious Disease, 3(108), 1-12. https://doi.org/10.3390/tropicalmed3040108

Gordon, C. A., Kurscheid, J., Williams, G. M., Clements, A. C., Li, Y., Zhou, X. N., ... \& Gray, D. J. (2019). Asian schistosomiasis: current status and prospects for control leading to elimination. Tropical medicine and infectious disease, 4(1), 40. https://doi.org/10.3390/tropicalmed4010040

Gunawan, G., Anastasia, H., Pamela, P., \& Risti, R. (2014). Contribution Animal Mammal Cattle, Buffalo, Horse, Pig and Dog in Infection Schistosomiasis in Sub District Lindu, District Sigi, Central Of Sulawesi Province 
2013. Media Litbangkes, 24, 209-214. https://doi.org/10.22435/mpk.v24i4.3676.209-214

Jourdan, P. M., Montresor, A., \& Walson, J. L. (2017). Building on the success of soil-transmitted helminth control-The future of deworming. PLoS neglected tropical diseases, 11(4), e0005497. https://doi.org/10.1371/journal.pntd.0005497

Kabore, A., Ibikounle, M., Tougoue, J. J., Mupoyi, S., Ndombe, M., Shannon, S., ... \& Awaca, N. (2017). Initiating NTD programs targeting schistosomiasis and soil-transmitted helminthiasis in two provinces of the Democratic Republic of the Congo: Establishment of baseline prevalence for mass drug administration. Acta tropica, 166, 177-185. https://doi.org/10.1016/j.actatropica.2016.11.023

Ministry of Health. (2019). Vector and Zoonosis in 2015-2019 (pp. 1-58).

Knowles, S. C., Webster, B. L., Garba, A., Sacko, M., Diaw, O. T., Fenwick, A., ... \& Webster, J. P. (2015). Epidemiological interactions between urogenital and intestinal human schistosomiasis in the context of praziquantel treatment across three West African countries. PLoS neglected tropical diseases, 9(10), e0004019. https://doi.org/10.1371/journal.pntd.0004019

Mitra, A. K., \& Mawson, A. R. (2017). Neglected tropical diseases: epidemiology and global burden. Tropical medicine and infectious disease, 2(3), 36. https://doi.org/10.3390/tropicalmed2030036

National Institute of Health Research and Development Ministry of Health Republic of Indonesia. (2019). Strategi nasional riset implementasi/operasional untuk mendukung pencegahan dan pengendalian Tuberkulosis, Malaria dan NNeglected Tropical Diseases.

Liang, Y. S., Dai, J. R., Ning, A., Yu, D. B., Xu, X. J., Zhu, Y. C., \& Coles, G. C. (2001). Susceptibility of Schistosoma japonicum to praziquantel in China. Tropical Medicine \& International Health, 6(9), 707-714. https://doi.org/10.22435/blb.v12i1.4455.1-6

Olveda, R. M., \& Gray, D. J. (2019). Schistosomiasis in the Philippines: Innovative control approach is needed if elimination is the goal. Tropical medicine and infectious disease, 4(2), 66. https://doi.org/10.3390/tropicalmed4020066

Ross, A. G., Chau, T. N., Inobaya, M. T., Olveda, R. M., Li, Y., \& Harn, D. A. (2017). A new global strategy for the elimination of schistosomiasis. International Journal of Infectious Diseases, 4, 130-137. https://doi.org/10.1016/j.ijid.2016.09.023

Ross, A. G., Olveda, R. M., McManus, D. P., Harn, D. A., Chy, D., Li, Y., ... \& Ng, S. K. (2017). Risk factors for human helminthiases in rural Philippines. International Journal of Infectious Diseases, 54, 150-155. https://doi.org/10.1016/j.ijid.2016.09.025

Satrija, F., Ridwan, Y., \& Rauf, A. (2015). Current status of schistosomiasis in Indonesia. Acta Tropica, 141, 349-353. https://doi.org/10.1016/j.actatropica.2013.06.014

Sumarni, S. (2011). The New Endemic Area of Schistosoma japonicum in Bada Highland Western Lore Subdistrict, District of Poso, Central Sulawesi Province. Tropical Medicine Journal, 1(1).

Widjaja, J., Anastasis, H., Nurwidayati, A., Nurjana, M. A., \& Maksud, M. (2017). Situasi Terkini Daerah Fokus Keong Hospes Perantara di Daerah Endemis Schistosomiasis di Sulawesi Tengah. Indonesian Bulletin of Health Research, 45(4), 215-222. https://doi.org/10.22435/bpk.v45i4.7570.215-222

Yu, W., Ross, A. G., Olveda, R. M., Harn, D. A., Li, Y., Chy, D., \& Williams, G. M. (2017). Risk of human helminthiases: geospatial distribution and targeted control. International Journal of Infectious Diseases, 55, 131-138. https://doi.org/10.1016/j.ijid.2016.12.013

\section{Copyrights}

Copyright for this article is retained by the author(s), with first publication rights granted to the journal.

This is an open-access article distributed under the terms and conditions of the Creative Commons Attribution license (http://creativecommons.org/licenses/by/4.0/). 